\title{
Control of Heavy Metals from Barley and Wheat Grains during Malting and Brewing
}

\author{
Gerhard Gramss*
}

Institute of Earth Sciences, Friedrich-Schiller-University, Burgweg 11, Jena D-07749, Germany

Received Date: May 01, 2020; Accepted Date: May 07, 2020; Published Date: May 18, 2020

"Corresponding Author: Gerhard Gramss, Institute of Earth Sciences, Friedrich-Schiller-University, Burgweg 11, Jena D-07749, Germany. Email: Gerhard.gramss@uni-jena.de

\section{Abstract}

Among seven wheat, rye, and pea crops from a nonremediable polymetallic soil with $39.6 \mathrm{mg} \mathrm{kg}^{-1}$ in $\mathrm{Cd}$, barley ranking fourth in grain production experienced the least yield losses in grains (37\% vs. 60-74\% in the other seed crops). With $0.455 \mathrm{mg} \mathrm{kg}^{-1}$ by dry weight in Cd vs. $1.20-3.13 \mathrm{mg} \mathrm{kg}^{-1}$ in the reference seeds, barley grains even met the limit of 1.0 $\mathrm{mg} \mathrm{kg}{ }^{-1}$ fresh weight set for livestock feed and human food supplements. Grains of barley and the wheat cvs. JB Asano (Cd, $1.55 \mathrm{mg} \mathrm{kg}^{-1}$ ) and Kavalier (Cd, $0.054 \mathrm{mg} \mathrm{kg}^{-1}$ ) were therefore used for the production of malt extract and beer to estimate consequences for their misuse in food processing. Heavy metals (HM) were monitored by Inductively Coupled Plasma Mass Spectrometry (ICP-MS) after microwave digestion. During micromalting of barley and wheat grains, $74 \%$ and $83 \%$, respectively, of $\mathrm{Cd}, \mathrm{Cr}, \mathrm{Cu}, \mathrm{Mn}, \mathrm{Pb}, \mathrm{U}$, and $\mathrm{Zn}$, followed by As and $\mathrm{Ni}$ with around $34 \%$, were removed from the mash with the spent grains that retained the cell wallbound $\mathrm{Cd}, \mathrm{Cu}, \mathrm{Ni}$, and $\mathrm{Zn}$ in values critical for livestock feed. With $\mathrm{Cd}$ concentrations of 0.019 and $0.041 \mathrm{mg} \mathrm{kg} \mathrm{kg}^{-1}$, respectively, the remaining turbid sweet wort used in 1:5.5 dilution met the limit of $0.1 \mathrm{mg} \mathrm{kg}^{-1}$ for solid food. Its fermentation with Saccharomyces cerevisiae precipitated another $79-98 \% \mathrm{Cd}$ and $31-93 \% \mathrm{As}, \mathrm{Cu}$, and $\mathrm{Zn}$ with their highest affinity to organic binding sites of residual tissue fragments and proteins but no further $\mathrm{Cr}, \mathrm{Mn}, \mathrm{Ni}, \mathrm{Pb}$, and $\mathrm{U}$ from solution. With the widest separation of organic-bound HM from the fraction of fermentable sugars, the resulting transparent barley and wheat beers concurred with the guidelines for drinking water and alcoholic beverages. It is argued that the exceptionally low grain acquisition of $\mathrm{Cd}, \mathrm{Ni}$,
$\mathrm{As}$, and $\mathrm{Pb}$ in barley accessions and the further $\mathrm{HM}$ control during processing shall not be concealed. If barley production is lightly extended to cropland with HM contaminations beyond regional guidelines, the exclusive use in husbandry and bioethanol production must be ensured to preclude future ignorance of any soil hygiene measures.

Keywords: Brewers' Wort; Cadmium; Malt; Mashing; Saccharomyces Cerevisiae, Spent Grains; Trub; Wheat and Barley Beer

\section{Introduction}

The need of a growing human world population in staple food, energy, industrial raw materials, and more stock farming products is uncontested. Nevertheless, these pretensions conflict with the loss of quality cropland to urbanization, sealing, mining, salinity, and land erosion [1-4]. Sewage and husbandry sludges, industrial effluents used as irrigation water, and arsenic (As), cadmium (Cd), and uranium (U) traces in phosphate fertilizers enrich heavy metals (HM) in soil [5-7]. In tolerating depreciated cropland, barley accessions with their greater acceptance of problematic soils, climatic drawbacks, and generally lower rates of As, Cd, nickel (Ni), and lead $(\mathrm{Pb})$ in the grains than other cereals [8-10] should thereby be the first choice.

With an annual world production of 136 to $160 \mathrm{Mio} \mathrm{Mg}$ and yields of $1800-6400 \mathrm{~kg} \mathrm{ha}^{-1}$ that are surpassed by values of $7600-11,000 \mathrm{~kg} \mathrm{ha}^{-1}$ in industrialized regions [11, 12], barley is ranking fourth behind the grain crops wheat, maize, and rice. In regions of high altitude, aridity, salinity, and other 
unfavorable conditions, the crop may become the only staple food resource [13-16].

Barley grains are used in malt, beer, and bioethanol production and serve as feed in husbandry [17]. Some health benefits such as heart disease, diabetes, and cancer prevention, body weight control, and reductions in total and LDL cholesterol [18-20] and blood sugar [21] are linked with barley consume. Barley straw is used for bedding in husbandry but also as roughage for ruminants in combination with alfalfa [22], hay, $14-30 \%$ proteins, a mineral mix, and salt [23, 24].

Among seven experimental crops of wheat, rye, and pea from a polymetallic soil with $39.6 \mathrm{mg} \mathrm{kg}^{-1}$ in Cd and 154,205 , 39 , and $3200 \mathrm{mg} \mathrm{kg}^{-1}$ in $\mathrm{As}, \mathrm{Cu}, \mathrm{U}$, and $\mathrm{Zn}$, respectively, barley experienced the least losses in grains (37\% vs. $60-74 \%$ ) and straw (0\% vs. $52-67 \%$ ) in comparison to crops from noncontaminated soils [8]. Heavy metal concentrations in the herbage of barley ranged within those of other seed crops and excluded its use as roughage supplement and bedding in husbandry by exceeding the permissible limit of $1.0 \mathrm{mg} \mathrm{kg}^{-1}$ [25] with $4.65 \mathrm{mg} \mathrm{kg}^{-1}$ in $\mathrm{Cd}$ [8]. HM concentrations in grains met those of other cereals, too, but were drastically lower in $\mathrm{Cd}$ and Ni. With $0.455 \mathrm{mg} \mathrm{kg}^{-1}$ by dry weight (DW) in $\mathrm{Cd}$ versus $1.20-3.13 \mathrm{mg} \mathrm{kg}^{-1}$ in the other seed crops, barley grains from soils of $39.6 \mathrm{mg} \mathrm{kg}^{-1}$ in Cd even met the limit of $1.0 \mathrm{mg}$ $\mathrm{kg}^{-1}$ fresh weight (FW) set for livestock feed and human food supplements $[\mathbf{8}, \mathbf{2 5}, \mathbf{2 6}]$. This is alarming in regard to the observation of soil and crop hygiene standards and has so far not yet been reported. Thereby, carelessly created perils for consumers of beer, malt amended food, and stock farming products by making the most of the legislative hygiene limits for $\mathrm{As}, \mathrm{Cd}$, and $\mathrm{Pb}[26]$ must be excluded. Contaminated and non-contaminated barley and wheat grains were therefore used for the production of malt extract and beer to estimate consequences for their misuse in food processing, but also for the possibility to separate the fermentable sugar fraction from HM contaminated tissues.

Subjacent to the two husks in dorsal and ventral position of the barley grain, the living cells of the outer and inner covering layers of pericarp and testa enclose the embryo and the dead cells of the starchy endosperm to stabilize seed dormancy by restricting ingress of oxygen. The endosperm itself is surrounded by three cell layers of the aleurone and separated from the embryo by the epithelial cells of the scutellum [27, 28]. Starch granules of the endosperm account for $60-65 \%$ by DW of the grain. Starch is composed of 17 $24 \% \mathrm{n}$-amylose that forms chains of 60-2000 glucose residues in $\alpha-1,4$ bonds. Amylopectin as the main component forms branched chains of glucose units in $\alpha-1,4$ and $\alpha-1,6$ bonds [27].

With the production of gibberellic acid (GA3) by the germinating embryo, the aleurone releases hemicellulases, proteolytic enzymes, amylases, and phosphatases for the 'modification' of the endosperm. In the major steps, glucanases break down its cell walls that primarily consist of $\beta$-D-glucan. Proteins encompassing the starch granules are degraded by proteases to lower molecular weight proteins, peptides, and amino acids. $\beta$-Amylase derives yeastfermentable maltose from both starch components. $\alpha$-Amylase generates oligodextrin (six glucose units) and branched dextrins that are further converted to maltose and maltotriose by $\beta$-amylase in the exclusive cleavage of $\alpha-1,4$ bonds. The remaining $20 \%$ of limit dextrins with $\alpha-1,6$ bonds are broken down by dextrin-6- $\alpha$-D-glucanohydrolase to dextrins accessible to $\beta$-amylase [27, 28].

Industrial protocols for the production of malts (malted grains) start with steeping barley and wheat in three successive batches of water at $12-18^{\circ} \mathrm{C}$ to raise the grain water content to $43-48 \%$ by total weight over $22-28 \mathrm{~h}$, interrupted by phases of aeration, and accompanied by a DW loss of $0.8 \%$. Supported by water spraying, grains germinate within six days at temperatures as low as $14-18^{\circ} \mathrm{C}$ to reduce the loss of biomass by respiration. The green malt of $160 \mathrm{~kg}$ per $100 \mathrm{~kg}$ of grains is then slowly dried by 'kilning' to $80 \mathrm{~kg}$ and a water content of $3-4 \%$ at temperatures of $50-77^{\circ} \mathrm{C}$, designed to support the grain internal enzymatic catalyses of starch to fermentable sugars. After removing the sprouts of roots and shoots that are enriched in trace metals by factors 2-6x [29], malt grains are crushed and mashed in aqueous suspensions of $1: 2.5$ to $1: 4$ $(w / v)$. The fermentable sugars of the resulting heated sweet wort are formed by maltase (at $\left.35-40^{\circ} \mathrm{C}\right)$, saccharase $\left(50^{\circ} \mathrm{C}\right)$, dextrin-6- $\alpha$-D-glucanohydrolase $\left(55-60^{\circ} \mathrm{C}\right), \beta$-amylase (62$\left.<70^{\circ} \mathrm{C}\right)$, and $\alpha$-amylase $\left(72-<75^{\circ} \mathrm{C}\right)$. Intermediate boiling half of the mash supports the dissolution of starch. The final mineral stock of the resulting beer may be given by the input sources of the original grains and the Al- and Cu-pesticide treated hop, reduced by the metal binding fractions of spent grains or draff, and the trub precipitate formed by fermenting yeasts [27, 29-31].

In adaptation to the procedures given above, barley and wheat grains obtained from contaminated and noncontaminated arable soils were processed to malt extract and fermented to beer with the goal to record the gradual removal of critical HM, especially of $\mathrm{Cd}$ and $\mathrm{Zn}$, with spent grains and trubs from the fraction of fermentable sugars under consideration of the ethics of food quality.

\section{Materials and Methods}

\section{Grain Crops}

Of the recent grain crops cultivated on polymetallic soils with abating HM load, a two-rowed winter barley cv. tested in the 2015/2016 season was chosen. It has been compared with the contaminated grains of the winter wheat cultivar JB Asano, an A-quality crop denoted by a high 1000 -seeds FW and an average raw protein content as described in detail [32]. The winter wheat $\mathrm{cv}$. Kavalier grown on non-contaminated arable derived from mottled sandstone in 2016/2017 [33] was used for comparative micromalting. 
Soils

With the local inclusion of aged polymetallic overburdened soil from uranium mining into noncontaminated cropland, a gradient of geologically related soils with diminishing HM concentrations had been formed in the late 1960s. The clay-loam soil was derived from Permian limestone, mottled sandstone, and dolomite [34]. Its mineral content was confirmed by the random collection of six soil samples from the $20-\mathrm{cm}$ plough layer. Soil (sieve $0.8 \mathrm{~mm}$ ) from the HM hot spot (Table 1) of $\mathrm{pH}_{\mathrm{aqu}} 7.12$ contained $3.53 \%$ in $\mathrm{C}_{\text {org. }}$. The winter wheat cv. Kavalier was obtained from an arable soil of $\mathrm{pH}_{\mathrm{aqu}} 6.85$ and $\mathrm{C}_{\mathrm{org}} 1.55 \%$ as derived from mottled sandstone.

\begin{tabular}{|c|c|c|c|c|c|c|c|c|}
\hline Cu & Mn & Ni & Zn & As & Cd & Cr & Pb & U \\
\hline \multicolumn{7}{|c|}{ Heavy metal hot spot of polymetallic soil } \\
\hline $171 \pm 5$ & $1932 \pm 4$ & $41.7 \pm 1$ & $3207 \pm 104$ & $144 \pm 5$ & $39.6 \pm 0.8$ & $22.5 \pm 1.6$ & $161 \pm 4$ & $33.3 \pm 0.6$ \\
\hline \multicolumn{7}{|c|}{ Non-contaminated arable soil on mottled sandstone } \\
\hline $8.4 \pm 1.2$ & $198 \pm 21$ & $6.49 \pm 0.56$ & $33.1 \pm 2.7$ & $3.62 \pm 0.38$ & $0.105 \pm 0.008$ & $12.9 \pm 2.1$ & $9.4 \pm 0.9$ & $0.547 \pm 0.056$ \\
\hline
\end{tabular}

Table 1: Heavy metal concentrations $\left(\mathrm{mg} \mathrm{kg}^{-1} \mathrm{DW} \pm \mathrm{SD}\right)$ of the arable soils used for cropping the current grain sources $(\mathrm{n}=6)$.

\section{Mineral Concentrations in Soils and Grains}

Mineral concentrations were determined for duplicate aqua regia-extracted 5-g samples of soils. Duplicate samples of fresh gains milled for analyses (Pulverisette 14; Fritsch $\mathrm{GmbH}$, Idar-Oberstein, Germany) were prepared from $10 \mathrm{~g}$ in FW each after careful washing with bideionized water. Samples of $0.3 \mathrm{~g}$ were microwave-digested in $\mathrm{HNO}_{3}(4 \mathrm{~mL})$ and $\mathrm{H}_{2} \mathrm{O}_{2}(1 \mathrm{~mL})$ (Mars Xpress; CEM GmbH, Kamp-Lintfort, Germany) and diluted to $150 \mathrm{~mL}$ with bideionized water. The solutions were analyzed by Inductively Coupled Plasma Mass Spectrometry (X series ICP-MS, Thermo, Waltham, MA, USA). The resulting detection limits (in $\mathrm{mg} \mathrm{kg}^{-1} \mathrm{DW}$ ) were as follows: 0.0005, Th; 0.002, Cd, Co, Cs, U; 0.005, Cr; 0.01, As, $\mathrm{Mn}, \mathrm{Pb} ; 0.02$, Cu, Sr; 0.03, Ba, Ni, Zn; 0.04, Fe; 0.1, Al, Mg; $0.4, \mathrm{~K}, \mathrm{Na} ; 1, \mathrm{P}$; and 3, Ca. Fractions of spent grains were dried and treated accordingly.

\section{Micromalting}

Grains of barley (20 g DW) and the wheat cv. JB Asano from polymetallic soil as well as the wheat cv. Kavalier from non-contaminated soil were washed twice in bideionized water and placed in weighed petri dishes $90 \mathrm{~mm}$ in diameter. With an intermediate break of $6 \mathrm{~h}$ to avoid damage by anoxic conditions, the grains were steeped in $20 \mathrm{~mL}$ bideionized water at $16^{\circ} \mathrm{C}$ for $20 \mathrm{~h}$ to reach a net water content of $40 \%$ by total weight. Germinating grains formed roots and sprouts up to $12-20 \mathrm{~mm}$ tall at $14-15^{\circ} \mathrm{C}$ over $6 \mathrm{~d}$. The softened grains with the vegetative outgrowth that accounted for $11-12 \%$ of the dry biomass were then crushed with mortar and pestle by omitting the fermentative kilning process and suspended in glass dishes with bideionized water at 1:5 (DW/v). Mashing in a water bath was done by incubation steps of $35^{\circ} \mathrm{C}$ for $20 \mathrm{~min}$; heating to $50^{\circ} \mathrm{C}$ within $15 \mathrm{~min} ; 50^{\circ} \mathrm{C}$ for $40 \mathrm{~min}$; heating to $62^{\circ} \mathrm{C}$ within $15 \mathrm{~min}$; and $62^{\circ} \mathrm{C}$ for $30 \mathrm{~min}$.

At this stage, half the mash as the carrier of activated enzymes was separated and left untreated. The remaining half was subjected to $68^{\circ} \mathrm{C}$ for $1 \mathrm{~h}$ to promote saccharification, boiled for 15 min to dissolve remaining starch and added to the untreated fraction. The resulting mash was incubated at $62^{\circ} \mathrm{C}$ for $2 \mathrm{~h}$, at $68^{\circ} \mathrm{C}$ for $1 \mathrm{~h}$, and at $80^{\circ} \mathrm{C}$ for $30 \mathrm{~min}$ for killing enzymes.

The sweet wort was separated by sieving $(0.25 \mathrm{~mm})$ and rinsing the remaining draff with bideionized water to reach a total yield of 1:4.0 to the grains' initial DW $(\mathrm{w} / \mathrm{w})$. Its mineral values were re-calculated for the 1:5.5 diluted pre-alcoholic worts used for $12 \%$ beers $[\mathbf{2 7}, \mathbf{3 5}]$. Aliquots of wort samples with specific gravities of around 1.07 were dried at $100^{\circ} \mathrm{C}$ to determine the content in solids, representing the malt extract. The procedures were repeated three times to obtain at least two congruent results.

\section{Fermentation of the Pre-Alcoholic worts by Saccharomyces Cerevisiae}

Triplicate samples of the pre-alcoholic sweet wort $(10$ $\mathrm{mL}$ ) were amended with $20 \mathrm{mg}$ dry baker's yeast (Netto Marken-Discount AG \& Co. KG, 93142 Maxhütte-Haidhof, Germany) and incubated under anoxic conditions at $20^{\circ} \mathrm{C}$ for $13 \mathrm{~d}$ with the goal to estimate consume and precipitation of HM in the presence of yeast cells [e.g., 31,36]. The final alcoholic supernatants were centrifuged at $14,000 \mathrm{~g}$ for $5 \mathrm{~min}$ by using centrifuged sweet wort samples as references.

\section{Statistical Treatments}

SPSS 8.0 software (SPSS Inc., Chicago, IL, USA) was used to calculate the standard deviations (SD) of duplicate to quadruplicate results and linear correlations, and to perform one-way analyses of variance.

\section{Results}

\section{Delay in Grain Germination by Heavy Metals}

The initial low-temperature germination of water-steeped grains $[\mathbf{2 7}, \mathbf{3 5}]$ was significantly affected by their heavy metal load. Grains of barley and JB Asano obtained from the polymetallic HM hot spot (Tables 1 and 2) missed the critical 
phytotoxicity thresholds of $5-10 \mathrm{mg} \mathrm{kg}^{-1}$ in $\mathrm{Cd}$ and persisted in the lower range of the $150-220 \mathrm{mg} \mathrm{kg}^{-1}$ in $\mathrm{Zn}[\mathbf{3 7 , 3 8 ]}$. Nevertheless, root and shoot emergence lagged 2 to 3 days behind that of gains from less contaminated soils (Figure 1). Germination was terminated when the sprouts had come to 11$12 \%$ of the original grains' DW.

\section{Micromalting with Heavy Metal Contaminated Grains}

Following micromalting, the DW of the sweet wort or malt extract per $\mathrm{kg}$ of dry barley grains obtained from polymetallic soil reached $51 \%$, leaving $39 \%$ to the draff fraction (Table 2). The wheat cv. Kavalier and the contaminated cv. JB Asano yielded 55 and 56\% dry wort beside 38 and $40 \%$ draff, respectively. The permissible contamination limits of $\mathrm{As}, \mathrm{Cd}$, and $\mathrm{Pb}$ for fresh food grains were only violated by barley and wheat grains from the polymetallic soil in regard of $\mathrm{Cd}$ (Table 2). Their trace metals $\mathrm{Cd}, \mathrm{Cr}, \mathrm{Cu}, \mathrm{Mn}, \mathrm{Pb}, \mathrm{U}$, and $\mathrm{Zn}$ were removed to $74.3 \pm 10.3 \%$ and $82.6 \pm 5.5 \%$, respectively, followed by As and $\mathrm{Ni}$ with around $34 \%$, with the spent grain or draff fractions from the mash. Contemporarily, the Cd load of the dry malt extracts as the solids of the sweet worts dropped to values below the permitted $1 \mathrm{mg} \mathrm{kg}^{-1} \mathrm{FW}$ for food supplements (Table 2) [26].
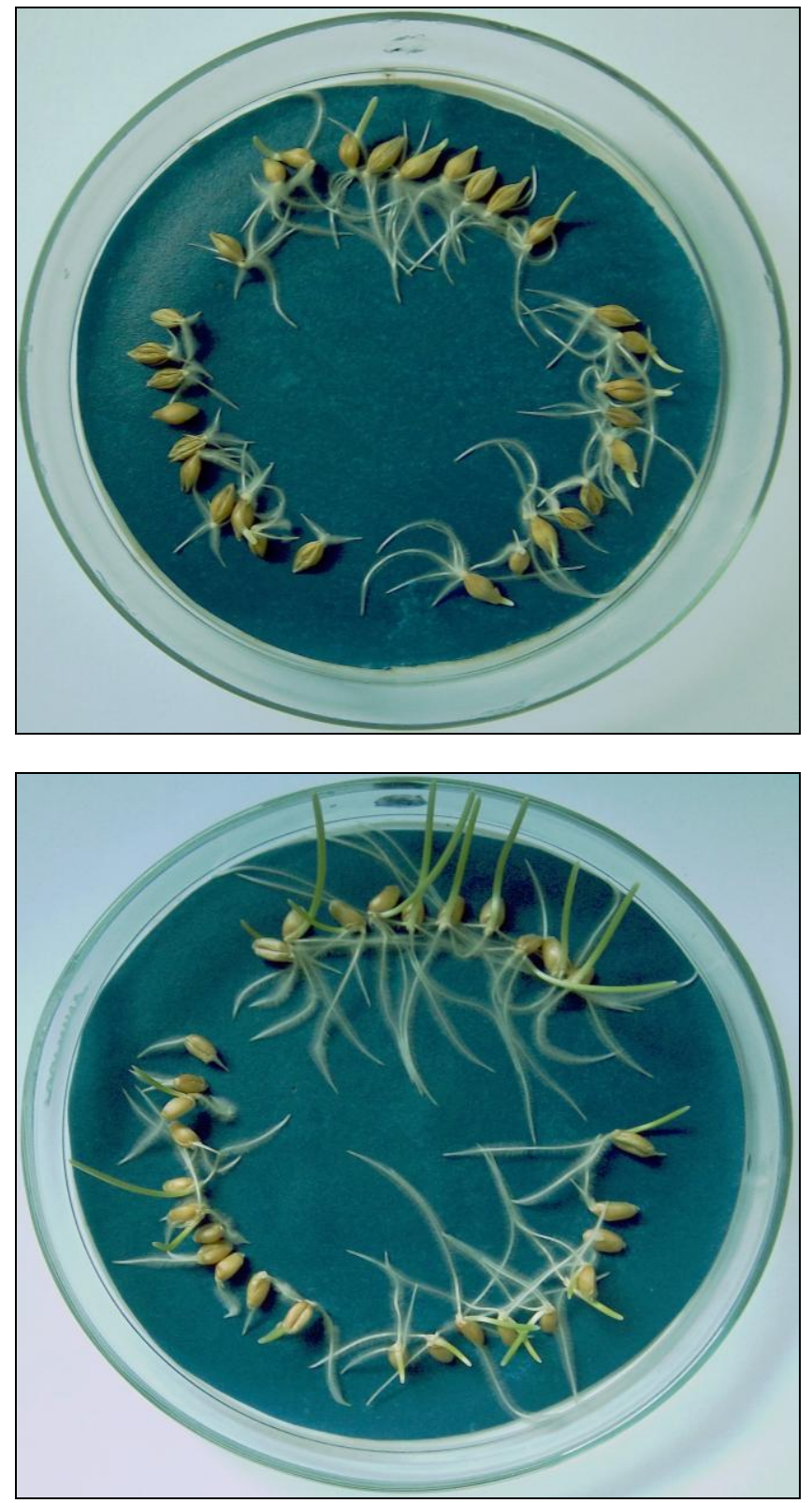

Figure 1: Germination at $22^{\circ} \mathrm{C}$ of three grain sets each from winter barley (above, after $57 \mathrm{~h}$ ) and winter wheat cv. JB Asano (below, after $100 \mathrm{~h}$ ) that differ in their heavy metal load. Cadmium/zinc content $\left(\mathrm{mg} \mathrm{kg}^{-1} \mathrm{DW}\right)$ of grain sets arranged left-aboveright: Barley, 0.455/160-0.010/31-0.215/89; wheat, 1.55/138-0.075/27-0.820/72. Further HM with phytotoxicity potential such as $\mathrm{As}, \mathrm{Cu}, \mathrm{Ni}$, and $\mathrm{Pb}$ persisted in the lower range of normal plant concentrations (Table 2). 


\begin{tabular}{|c|c|c|c|c|c|c|c|c|c|c|}
\hline Item & $\mathrm{Cu}$ & Mn & $\mathbf{N i}$ & $\mathbf{Z n}$ & As & Cd & $\mathrm{Cr}$ & $\mathbf{P b}$ & $\mathbf{U}$ & Product $^{\mathrm{a}}$ \\
\hline \multicolumn{11}{|c|}{ Winter wheat cv. Kavalier form non-contaminated soil } \\
\hline Grains & $4.45^{\mathrm{b}}$ & 26.8 & 0.071 & 30.7 & 0.019 & 0.054 & $0.005^{\mathrm{b}}$ & $0.013^{\mathrm{b}}$ & 0.003 & - \\
\hline Malt & 1.38 & 4.46 & 0.126 & 8.74 & 0.03 & 0.015 & 0.022 & 0.026 & 0.004 & 0.5486 \\
\hline Draff & 7.4 & 52.9 & 0.114 & 74.2 & 0.025 & 0.166 & 0.078 & 0.137 & 0.004 & 0.3834 \\
\hline Wort & 0.138 & 0.445 & 0.013 & 0.876 & 0.003 & 0.0015 & 0.002 & 0.003 & 0.001 & - \\
\hline \multicolumn{11}{|c|}{ Winter barley from contaminated soil A } \\
\hline Grains & 6.1 & 12.5 & 0.37 & 160 & 0.125 & 0.455 & 0.165 & 0.044 & 0.007 & - \\
\hline Malt & 3.85 & 5.08 & 0.644 & 75.5 & 0.146 & 0.202 & 0.028 & 0.049 & 0.008 & 0.5106 \\
\hline Draff & 12.8 & 23 & 0.415 & 331 & 0.1 & 1.13 & 0.345 & 0.128 & 0.013 & 0.3891 \\
\hline Wort & 0.358 & 0.472 & 0.06 & 7.01 & 0.014 & 0.019 & 0.003 & 0.005 & 0.001 & - \\
\hline Beer & $0.051^{\mathrm{c}}$ & 0.481 & 0.06 & $4.82^{\mathrm{c}}$ & $0.001^{\mathrm{c}}$ & $0.004^{\mathrm{c}}$ & 0.004 & 0.004 & 0.001 & - \\
\hline \multicolumn{11}{|c|}{ Winter wheat JB Asano from contaminated soil A } \\
\hline Grains & 6.43 & 19.9 & 2.09 & 138 & 0.1 & 1.55 & 0.075 & 0.044 & 0.006 & - \\
\hline Malt & 2.57 & 4.96 & 2.65 & 37.3 & 0.108 & 0.398 & 0.033 & 0.022 & 0.004 & 0.562 \\
\hline Draff & 14.6 & 45.4 & 1.81 & 353 & 0.085 & 3.63 & 0.245 & 0.164 & 0.013 & 0.3969 \\
\hline Wort & 0.262 & 0.507 & 0.27 & 3.81 & 0.011 & 0.041 & 0.003 & 0.002 & 0.001 & - \\
\hline Beer & $0.030^{c}$ & $0.458^{\mathrm{c}}$ & $0.239^{\mathrm{c}}$ & $1.45^{\mathrm{c}}$ & $0.002^{\mathrm{c}}$ & $0.001^{\mathrm{c}}$ & 0.005 & 0.004 & 0 & - \\
\hline \multicolumn{11}{|c|}{ Usual heavy metal range of herbs (in $\left.\mathrm{mg} \mathrm{kg}^{-1} \mathrm{DW}\right)^{\mathrm{d}}$} \\
\hline- & $2-20$ & $14-30$ & $0.1-3$ & $10-100$ & $0.01-1$ & $0.05-0.4$ & $0.1-1$ & $0.1-6$ & $<0.015$ & - \\
\hline \multicolumn{11}{|c|}{ WHO 2011 limits for drinking water } \\
\hline WHO & 2 & - & 0.07 & - & 0.01 & 0.003 & 0.05 & 0.01 & 0.03 & - \\
\hline \multicolumn{11}{|c|}{$\begin{array}{l}\text { a Dry weight }(\mathrm{kg}) \text { of wort and draff recovered from one } \mathrm{kg} \text { of dry grains. } \\
\text { b Unlike the majority of values, the marked ones differ significantly at } \mathrm{p} \leq 0.05 \text { from the sum of the total mineral portions } \\
\text { represented by dry malt extract and draff. } \\
\mathrm{c}^{\mathrm{a}} \text { Mineral concentrations in beer differ significantly at } \mathrm{p} \leq 0.05 \text { from those of sweet wort. } \\
\text { d Normal plant heavy metal concentrations [39,40]. } \\
\text { Permissible contamination limits for food grains in } \mathrm{mg} \mathrm{kg}^{-1} \mathrm{FW} \text { : As, } 0.5 ; \mathrm{Pb}, 0.2 ; \mathrm{Cd}, 0.1 \text { for cereals, } 0.2 \text { for wheat and rice [26]. }\end{array}$} \\
\hline
\end{tabular}

Table 2: Micromalting 20-g samples of barley and wheat grains $(\mathrm{n}=2)$ : Mean trace metal concentrations of sweet wort $(1: 5.5 \mathrm{w} / \mathrm{v})$ and beer given in $\mathrm{m} \mathrm{L} \mathrm{L}^{-1}$ and those from fresh grains, the dry malt extract (malt), and the draff fraction in $\mathrm{m} \mathrm{kg}^{-1} \mathrm{DW}$.

Further trace mineral concentrations refer to the sweet worts diluted to $5.5 \mathrm{~L}$ per kg of dry grains as immediately used for $12 \%$ beers [27], and for their alcoholic beer state fermented by HM fishing baker's yeast $[\mathbf{3 1}, \mathbf{3 6}]$.

Incubation of the sweet turbid worts with Saccharomyces cerevisiae formed the transparent alcoholic beer fractions and sent As (82-93\%), Cd (79-98\%), Cu (86-88\%), and $\mathrm{Zn}(31-$ $62 \%)$ to the trubs. Their DW came to $0.77 \%$ and $0.71 \%(\mathrm{w} / \mathrm{v}$, referred to wort dilution 1:5.5) in barley and wheat beer, respectively. Thereby, $\mathrm{Cr}, \mathrm{Mn}, \mathrm{Ni}, \mathrm{Pb}$, and $\mathrm{U}$ were not removed from solution. Centrifuging wort aliquots revealed that the fermenting yeast incorporated $1.3-1.7 \mathrm{mg} \mathrm{L}^{-1}$ of $\mathrm{Zn}$ as cofactor of alcohol dehydrogenase [27], but no significant amounts of the other elements. All trace mineral concentrations of wheat cv. Kavalier grains from noncontaminated soils as well as their fermenting products fitted the legislative ranges of food safety [26].

\section{Discussion}

The inherently out regulated and low metallome of seeds ensures the adequate mineral supply of the early germling by avoiding metal stress [41]. Accordingly, in spite of elevated burdens in $\mathrm{As}, \mathrm{Cd}, \mathrm{Cu}, \mathrm{Mn}, \mathrm{U}$, and $\mathrm{Zn}$ of the polymetallic soil, barley and wheat grains persisted the widest in the usual and metal stress avoiding HM range of herbs but were somewhat higher in $\mathrm{Cd}$ and $\mathrm{Zn}$ (Table 2). Contaminations with $\mathrm{Cd}$ [42, 43] more than those with $\mathrm{Cu}>\mathrm{Zn}>\mathrm{Pb}$ [44] generally impair the germination of wheat and should contribute to the 2-3 days of delay in the sprouting of steeped barley and wheat grains from the polymetallic soil (Figure 1). The resulting green malt was neither kilned nor stripped of the HM enriched sprouts of $11-12 \%$ by DW as is done in the production of dry malt grains $[27,35]$. Outgrowing roots and cotyledons can surpass the remaining grains in the concentrations of $\mathrm{Ni}(2 \mathrm{x}), \mathrm{Zn}(3 \mathrm{x}), \mathrm{As}$, $\mathrm{Cu}, \mathrm{Hg}, \mathrm{Pb}(3-5 \mathrm{x})$, and $\mathrm{Cd}$ and $\mathrm{Cr}(6 \mathrm{x})$ [29]. The content of the contaminated and stripped barley and wheat grains would thereby drop to $71 \%$ in $\mathrm{Zn}$ and $55 \%$ in Cd, respectively, prior to mashing. By including the HM load of the outgrown sprouts, both draff of barley and wheat from the polymetallic 
soil would concur with the tolerable limits of livestock animals in $\mathrm{Zn} \mathrm{(300-1000} \mathrm{mg} \mathrm{kg-1)} \mathrm{[45]} \mathrm{but} \mathrm{not} \mathrm{in} \mathrm{Cd} \mathrm{(1} \mathrm{mg} \mathrm{kg-}$ ${ }^{1} \mathrm{FW}$ ) [25] (Table 2). Therefore, the spent grains should be fed, if at all, as $10 \%$ supplements.

The preferential binding of trace minerals to, and their relative enrichment in the separable draff fractions at $74-83 \%$ (Table 2) deserves attention. If surplus minerals are not located in vacuoles, they meet variable binding sites in cell walls $[46,47]$. In addition, sound wheat straw [48] but also humic and fulvic acids released from senescent plants [49] and derived from biomass [50-52] unite phenolic and flavone units with terpenoids, alkanes, sugars, aliphatic and aromatic acids, tannins, heterocyclics, alcohols, amino sugars, amino acids, peptides, and proteins. Their reactive dissociable groups are mainly carboxyl (-COOH), phenolic, enolic, and alcoholic hydroxyl (-OH), methoxyl $\left(-\mathrm{OCH}_{3}\right)$, sulphydryl (-SH), amino $\left(-\mathrm{NH}_{2}\right)$, and imino $(=\mathrm{NH})$ type whose protons $\left(\mathrm{H}^{+}\right)$are exchangeable with metal cations [53]. Thereby, cations such as $\mathrm{Zn}^{2+}>\mathrm{Cu}^{+}>\mathrm{Cu}^{2+}>\mathrm{Ni}^{2+}>\mathrm{Co}^{2+}>\mathrm{Fe}^{2+}>\mathrm{Mn}^{2+}>\mathrm{Mg}^{2+}>$ $\mathrm{Ca}^{2+}$ that most successfully compete for the respective binding sites [54] are primarily removed, with $\mathrm{Cd}$ having not been considered [55].

Accordingly, the remaining $\mathrm{Cd}$ load in the dry malt extracts from barley and wheat grains from the polymetallic soil $\left(\mathrm{Cd}, 39.6 \mathrm{mg} \mathrm{kg}^{-1}\right)$ ranged, as the fresh barley grains themselves, safely below the elevated appearing limit of $1 \mathrm{mg}$ $\mathrm{kg}^{-1} \mathrm{FW}$ set for food supplements [26]. It further dropped to solid-food-grade values of $\leq 0.1 \mathrm{mg} \mathrm{kg}^{-1} \mathrm{FW}$ in the sweet turbid wort (Table 2) that is used at 5.5 to $6 \mathrm{hL}$ per $100 \mathrm{~kg}$ of original grains in $12 \%$ beers [27].

The remarkably low trace mineral stock of the resulting barley and wheat beers were in the order those reported for commercial products and laid in $\mathrm{Zn}$ below the OIV limit for alcoholics [56-58]. Thereby, even the higher sweet wort concentrations in (As), $\mathrm{Cr}, \mathrm{Cu}, \mathrm{Pb}, \mathrm{U}$ and in $\mathrm{Ni}$ from barley beer concurred with the limits set for drinking water but raised concern in regard of $\mathrm{Cd}$ that is confined to $0.003 \mathrm{mg} \mathrm{L}^{-1}$ in water (Table 2) [59] and to $0.005-0.01 \mathrm{mg} \mathrm{L}^{-1}$ in liquid baby food [26]. Alcoholic beverages have been delimited to ( $\mathrm{mg} \mathrm{L}^{-}$ $\left.{ }^{1}\right) 0.01$ in $\mathrm{Cd}, 1.0$ in $\mathrm{Cu}, 0.15$ in $\mathrm{Pb}$, and 5.0 in $\mathrm{Zn}$ by the Organization of International Vine and Wine (OIV) [60]. Zinc concentrations in this order are thereby linked with metallic taste.

Fermenting the sweet worts from barley and wheat, respectively, removed $\mathrm{As}, \mathrm{Cd}$, and $\mathrm{Cu}$ to $79-98 \%, \mathrm{Zn}$ to $31-$ $62 \%$, but none of the traces $\mathrm{Cr}, \mathrm{Mn}, \mathrm{Ni}, \mathrm{Pb}$, and $\mathrm{U}$ from solution and led to beer concentrations in the range of drinking water (Table 2). This suggests preferential binding of As, Cd, and $\mathrm{Cu}$ to carboxyl groups of insufficiently degraded cell wall pectins [61] as polymers of $\alpha$ - $(1,4)$-linked D-galacturonic acid [62], to dissociable $\mathrm{COOH}, \mathrm{OH}$, and $\mathrm{NH}_{(2)}$ groups of amino, imino acids, and amides as moieties of proteins [55] that may envelope residual starch granules, and to cell debris fragmented by crushing the green malt. The hypothetical daily consume of $2 \mathrm{~L}$ sweet wort mashed from green barley and wheat malts with their HM enriched sprouts from the polymetallic soil would contribute $6.3 \%$ and $13.7 \%$, respectively, to the tolerable daily intake (TDI) of $0.6 \mathrm{mg} \mathrm{Cd}$ by a $75 \mathrm{~kg}$ individual $[26,59]$. Inputs of $\mathrm{HM}$ from hop supplements and from installations are not considered.

The present results concur with those of Čejka et al. [29]. Brewing water of barley was enriched with $\mathrm{As}, \mathrm{Cd}, \mathrm{Cr}, \mathrm{Hg}$, $\mathrm{Ni}, \mathrm{Se}$, and $\mathrm{Pb}$ to total concentrations of $0.1-2 \mathrm{mg} \mathrm{L}^{-1}$ in the mash. Compared with the HM input by the current barley and wheat grains into a mash of 1:4 (w/v), the enriched mash concentrations exceeded means of the (Table 2) derived data $14 \mathrm{x}$ in $\mathrm{As}, 43 \mathrm{x}$ in $\mathrm{Cr}$, and $76 \mathrm{x}$ in $\mathrm{Pb}$. They exceeded $\mathrm{Cd}$ and $\mathrm{Ni}$ concentrations $2 \mathrm{x}$ and 22x, respectively, in barley but matched those introduced with the grains of JB Asano. The authors obtained quality beer due to the removal of around $76-96 \%$ of the total irritants with the spent grains fraction and another 1$11 \%$ with the trub [29]. Nevertheless, the uncontested reputation of brewery and the acceptance of its produce are based on the exclusive use of highest quality raw materials [63]. Thereby, food crops elevated in agrochemicals, mycotoxins, organic contaminants, or irritants such as As, Cd, and $\mathrm{Pb}$ with their carcinogenic, nephrotoxic, and cardiovascular effects, respectively [59] that multiply in their mutual interaction [64] are excluded from wholesale trade prior to distribution [65]. This comprises grains from soils that do not match with the regional hygiene guidelines [e.g., 66]. They are to be rated as forage or industrial crops in responsibility of the grower [32].

\section{Conclusions}

Unlike the drastic losses in the production of seeds (60$74 \%$ ) among preceding cultures of wheat, rye, and pea from a non-remediable polymetallic soil of $39.6 \mathrm{mg} \mathrm{kg}^{-1}$ in Cd, barley experienced the least incisions in the formation of grains (37\%) [8]. Thereby, Cd exclusion led to elevated grain concentrations of $1.55 \mathrm{mg} \mathrm{kg}^{-1} \mathrm{DW}$ in the wheat cv. JB Asano but to $0.455 \mathrm{mg} \mathrm{kg}^{-1}$ in barley to meet the legislative limit of 1 $\mathrm{mg} \mathrm{kg}-1$ FW for livestock feed and even for human food supplements. Mashing removed $\mathrm{Cd}$ with the spent grain fraction to $81 \%$ in barley and to $87 \%$ in wheat. Whereas the resulting dry malt extracts concurred with the hygiene standards of $\mathrm{Cd}$ for food supplements, the sweet worts at the final dilution 1:5.5 met the limit of $0.1 \mathrm{mg} \mathrm{kg}^{-1} \mathrm{FW}$ set for solid food. Cadmium concentrations dropped further to 1-4 $\mu \mathrm{g}$ $\mathrm{L}^{-1}$ during alcoholic fermenting and the removal of trub below $0.01 \mathrm{mg} \mathrm{L}^{-1}$ set for alcoholic beverages. Thereby, the association of $\mathrm{As}, \mathrm{Cd}, \mathrm{Cu}$ and some $\mathrm{Zn}$, but not of $\mathrm{Cr}, \mathrm{Mn}, \mathrm{Ni}$, $\mathrm{Pb}$, and $\mathrm{U}$ with wort muddying colloids such as surmised pectin and protein-starch adducts with metal chelating properties should be a topic of further studies. It is recommended that the pronounced tolerance of $\mathrm{HM}$ contaminated soils by barley lines and their unique trait of $\mathrm{Cd}$ exclusion [8] should not lightly lead to crop production on intolerably contaminated soils and to undermining of soil hygiene standards, even if subsequent crop processing eliminates the majority of contaminants from the fermentable sugar fraction. Nevertheless, with its adaptability to detrimental 
climate and soil conditions and its potential health benefits, production and consume of barley deserve more attention.

Author Contributions: Conducted the experimental part and elaborated the script, G. G.

Funding: This research received no external funding.

Conflicts of Interest: The author declares no conflicts of interest.

\section{References}

1. Ettler V (2016) Soil contamination near non-ferrous metal smelters: A review. Appl Geochem 64: 56-74.

2. Nam SM, Kim M, Hyun S, Lee SH (2010) Chemical attenuation of arsenic by soils across two abandoned mine sites in Korea. Chemosphere 81:1124-1130.

3. Nair PKR (2014) Grand challenges in agroecology and land use systems. Front Environ Sci 2:1.

4. Bringezu S, Schütz H, Pengue W, O’Brien M, Garcia F et al. (2014) United Nations Environment Programme. Assessing Global Land Use: Balancing Consumption with Sustainable Supply. A Report of the Working Group on Land and Soils of the International Resource Panel.

5. Bigalke M, Ulrich A, Rehmus A, Keller A (2017) Accumulation of cadmium and uranium in arable soils in Switzerland. Environ Pollut 221:85-93.

6. Chandra R, Bharagava RN, Yadav S, Mohan D (2009) Accumulation and distribution of toxic metals in wheat (Triticum aestivum L.) and Indian mustard (Brassica campestris L.) irrigated with distillery and tannery effluents. J Hazard Mater 162:1514-1521.

7. Wuana RA, Okieimen FE (2011) Heavy metals in contaminated soils: A review of sources, chemistry, risks and best available strategies for remediation. ISRN Ecol: 402647.

8. Gramss G, Voigt K-D (2017) Seed crops reduce quality losses caused by soils of extreme mineral spans. In Agricultural Research Updates Vol. 21; Gorawala P, Mandhatri S eds; Nova Science Publishers, Inc., New York: 1-56.

9. Brunetti G, Farrag K, Soler-Rovira P, Ferrara M, Nigro F et al. (2012) Heavy metals accumulation and distribution in durum wheat and barley grown in contaminated soils under Mediterranean field conditions. J Plant Interact 7:160-174.

10. Adams ML, Zhao FJ, McGrath SP, Nicholson FA, Chalmers A et al. (2001) Cadmium and lead in British wheat and barley: survey results and factors affecting their concentration in grain (HGCA Project Report No. 265). Home Grown Cereals Authority (HGCA) London. (Accessed on 8 May 2018).

11. Top agrar (2010) The south relies on two-row winter barley. (Accessed on 24 January 2017).

12. Vorinformation LSV Wintergerste 2-zeilig - Stand: 22.07.16. LfL Pflanzenbau, IPZ 2a/SGVB - Juli 2016. (Accessed on 24 January 2017).
13. Akar T, Avci M, Dusunceli F (2004) BARLEY: PostHarvest Operations. FAO, Food and Agriculture Organization of the United Nations. (Accessed on 22 November 2018).

14. The Biology of Hordeum vulgare L (barley) (2008). Australian Government, Department of Health and Ageing, Office of the Gene Technology Regulator. (Accessed on 22 November 2018).

15. FAOSTAT (2017) Crops/Regions/World List/Production Quantity for Barley 2016 (pick list). UN Food and Agriculture Organization Corporate Statistical Database (FAOSTAT), 2017.

16. Dawson IK, Russell J, Powell W, Steffenson B, Thomas WT et al. (2015) Barley: a translational model for adaptation to climate change. New Phytol 206:913-931.

17. Lemaux P, Alonso B, Hertsgaard K (2011) Uses of barley, (accessed on 22 November 2018).

18. Ames NP, Rhymer CR (2008) Issues surrounding health claims for barley. J Nutr 138: 1237S-1243S.

19. Cho SS, Qi L, Fahey GC Jr, Klurfeld DM (2013) Consumption of cereal fiber, mixtures of whole grains and bran, and whole grains and risk reduction in type 2 diabetes, obesity, and cardiovascular disease. Am J Clin Nutr 98:594-619.

20. Ware M (2018) What are the health benefits of barley? (Accessed on 22 November 2018).

21. Groves M (2018) Is barley good for you? Nutrition, benefits and how to cook it. (Accessed on 22 November 2018).

22. Lofgreen GP, Christensen AC (1962) Barley straw as an energy source for growing beef steers. J Animal Sci 21:262-265.

23. Lyons T, Caffrey PJ, O'Connell WJ (1970) The effect of energy, protein and vitamin supplementation on the performance and voluntary intake of barley straw by cattle. Animal Sci 12: 323-334.

24. Yan Q, Tang S, Tan Z, Zhou C, Basang Z et al. (2018) Replacement of oat grass with highland barley straw: Effects on lipid profiles, FA composition and lipogenetic genes expression in Tibetan sheep. Ital J Animal Sci 17: 628-635.

25. The European Parliament and the Council of the European Union (2002). Directive 2002/32/EC of the European Parliament and of the Council of 7 May 2002 on undesirable substances in animal feed. Off $\mathbf{J}$ Eur Commun 140:10-21.

26. European Communities (2006). Commission regulation (EC) No 1881/2006 of December 2006 on setting maximum levels of certain contaminants in foodstuffs. Off J Eur Commun 364:5-24.

27. Narziss L (2005) Abriss der Bierbrauerei, $7^{\text {th }}$ ed.; WileyVCH: Weinheim, Germany.

28. Palmer GH (1992) Cereal science and malting technology-the future. ASBC J 50:121-130.

29. Čejka P, Horák T, Dvořák J, Čulík J, Jurková M (2011) Monitoring of the distribution of some heavy metals during brewing process. Ecol Chem Engineering 18: 6774 . 
30. Mochaba F, O'Connor-Cox ESC, Axcell BC (1996) Effects of yeast quality on the accumulation and release of metals causing beer instability. J Am Soc Brewing Chemists 54:164-171.

31. Wang J, Chen C (2006) Biosorption of heavy metals by Saccharomyces cerevisiae: A review Biotechnol Adv 24:427-451.

32. Gramss G, Voigt K-D (2016) Gradual accumulation of heavy metals in an industrial wheat crop from uranium mine soil and the potential use of the herbage. Agriculture 6:51.

33. Gramss G, Voigt K-D (2018) Turnover of minerals and organics in the postharvest herbage of annuals and perennials: Winter wheat and goldenrod. Agriculture 8:170.

34. Tonndorf H (1994) Metallogenie des Urans im ostdeutschen Zechstein : ein Beitrag zum Nachweis und zur Charakteristik hypergener stofflicher Umverteilungsund Anreicherungsprozesse.In Abhandlungen der Sächsischen Akademie der Wissenschaften zu Leipzig, Mathematisch-naturwissenschaftliche Klasse, Band 58, Heft 3; Akademie Verlag: Berlin, Germany.

35. Dabija A (2012). A study establishing an optimum malting diagram. Food Environ Safety 11:85-90.

36. Shen $Y$, Zheng $X$, Wang $X$, Wang $T$ (2018) The biomineralization process of uranium(VI) by Saccharomyces cerevisiae - transformation from amorphous $\mathrm{U}(\mathrm{VI})$ to crystalline chernikovite. Appl Microbiol Biotechnol 102:4217-4229.

37. Marschner H (1995) Mineral Nutrition of Higher Plants, $2^{\text {nd }}$ ed.; Academic Press: London, UK.

38. Sauerbeck D (1983) Welche Schwermetallgehalte in Pflanzen dürfen überschritten werden, um Wachstumsbeeinträchtigungen $\mathrm{zu}$ vermeiden? Landwirtsch. Forsch 39:108-129.

39. Schachtschabel P, Blume HP, Brümmer G, Hartge KH, Schwertmann U (1998) Lehrbuch der Bodenkunde, $14^{\text {th }}$ ed.; Enke: Stuttgart, Germany.

40. Auermann E, Dässler H-G, Jacobi J, Cumbrowski J, Meckel U (1980) Untersuchungen zum Schwermetallgehalt von Getreide und Kartoffeln. Die Nahrung 24:925-937.

41. Gramss G, Voigt K-D (2016) Stability of the inherent target metallome in seed crops and a mushroom grown on soils of extreme mineral spans. Agronomy 6:14.

42. Ahmad I, Akhtar MJ, Zahiri ZA, Jamil A (2012) Effect of cadmium on seed germination and seedling growth of four wheat (Triticum aestivum L.) cultivars. Pak J Bot 44:1569-1574.

43. Rizwan M, Ali S, Abbas T, Zia-ur-Rehman M, Hannan F et al. (2016) Cadmium minimization in wheat: A critical review. Ecotox Environ Saf 130:43-53.

44. Mahmood T, Islam KR, Muhammad, S (2007) Toxic effects of heavy metals on barley growth and tolerance of cereal crops. Pak J Bot 39:451-462.

45. McDowell LR (2003) Minerals in Animal and Human Nutrition, $2^{\text {nd }}$ ed.; Elsevier Science: Amsterdam.

46. Seregin IV, Ivanov VB (2001) Physiological aspects of cadmium and lead toxic effects on higher plants. Russian J Plant Physiol 48:523-544.
47. Suman J, Uhlik O, Viktorova J, Macek T (2018) Phytoextraction of heavy metals: A promising tool for clean-up of polluted environment? Front Plant Sci 9:1476.

48. Schnitzer M, Monreal CM, Powell, EE (2014) Wheat straw biomass: A resource for high-value chemicals. J Environ Sci Health 49:51-67.

49. Susic M (2016) Replenishing humic acids in agricultural soils. Agronomy 6:45.

50. Knicker H, Fründ R, Lüdemann H-D (1993) The chemical nature of nitrogen in native soil organic matter. Naturwissenschaften 80:219-221.

51. Sonnenberg LB, Johnson JD, Christman RF (1988) Chemical degradation of humic substances for structural characterization. In Aquatic Humic Substances: Influence on Fate and Treatment of Pollutants; American Chemical Society: Washington, DC, USA 219: 3-23.

52. Woods GC, Simpson MJ, Koerner PJ, Napoli A, Simpson AJ (2011) HILIC-NMR: Toward the identification of individual molecular components in dissolved organic matter. Environ Sci Technol 45:3880-3886.

53. Gramss G, Voigt K-D (2018) Turnover of minerals and organics in the postharvest herbage of annuals and perennials: Winter wheat and goldenrod. Agriculture 8:170.

54. Irving H, Williams RJP (1948) Order of stability of metal complexes. Nature 162:746-747.

55. Gramss G, Schubert R, Bergmann H (2009) Control of the root-to-shoot translocation of (heavy) metals in Chinese cabbage by application of carbon and nitrogen compounds to uranium mine dump soil. In Uranium: Compounds, Isotopes and Applications; Wolfe, G.H., Ed; Nova Science Publishers: NewYork, USA: 95-119.

56. Donadini G, Spalla S, Beone GM (2008) Arsenic, cadmium and lead in beers from the Italian market. J Inst Brew 114:283-288.

57. Oz S, Teke G, Ertan Anli R, Atakol O (2015) Heavy metal content of selected some Turkish beers. Int J Sci Tech Res 1:46-56.

58. Voica C, Magdas D-A, Feher I (2015) Metal content and stable isotope determination in some commercial beers from Romanian markets. J Chemistry (Hindawi): 192032.

59. WHO Drinking Water (2011) Guidelines for DrinkingWater Quality, $4^{\text {th }}$ ed.; ISBN 9789241548151.

60. OIV (2011) Compendium of International Methods of Analysis-OIV. Maximum acceptable limits of various substances contained in wine; International Organisation of Vine and Wine. OIV-MA-C1-01: R2011.

61. Cheng Y, Wang C, Chai S, Shuai W, Sha L (2018) Ammonium $\mathrm{N}$ influences the uptakes, translocations, subcellular distributions and chemical forms of $\mathrm{Cd}$ and $\mathrm{Zn}$ to mediate the $\mathrm{Cd} / \mathrm{Zn}$ interactions in dwarf polish wheat (Triticum polonicum L.) seedlings. Chemosphere 193:11641171.

62. Buchanan BB, Gruissem W, Jones RL (2000) Biochemistry and Molecular Biology of Plants. American Society of Plant Biologists: Rockville, MD, USA.

63. BEST_Roestmalz_eXtra.pdf. Product specification. https://bestmalz.de/wp-content/uploads/2015/12/2015- 


\section{Control of Heavy Metals from Barley and Wheat Grains} during Malting and Brewing
12_Technical_Data_Sheet_dt_25-

BEST_Roestmalz_eXtra.pdf (accessed on 2 May 2019).

64. Huang M, Zhou S, Sun B, Zhao Q (2008) Heavy metals in wheat grain: Assessment of potential health risk for inhabitants in Kunshan, China. Sci Total Environ 405:5461.
65. Etteldorf Landhandel - Metterich Eifel (2009) Allgemeine Einkaufsbedingungen für Getreide, Ölsaaten, Leguminosen und nachwachsende Rohstoffe. (Accessed on 2 May 2019).

66. BBodSchV (1999) Bundes-Bodenschutz- und Altlastenverordnung (BBodSchV). (Accessed on 12 December 2014).

Citation: Gramss G (2020) Control of Heavy Metals from Barley and Wheat Grains during Malting and Brewing. Adv in Nutri and Food Sci: ANAFS-184. 